KATARINA MOSTARAC, Ph.D. ${ }^{1}$

(Corresponding author)

E-mail: kmostarac@fpz.hr

ZVONKO KAVRAN, Ph.D. ${ }^{1}$

E-mail: zkavran@fpz.hr

ESTERA RAKIĆ, Ph.D. ${ }^{2}$

E-mail: estera.rakic@posta.hr

1 University of Zagreb

Faculty of Transport and Traffic Sciences

Vukelićeva 4, 10000 Zagreb, Croatia

${ }^{2}$ Croatian Post

Jurišićeva 13, 10000 Zagreb, Croatia
Traffic Planning

Preliminary Communication

Submitted: 13 June 2018

Accepted: 5 Feb. 2019

\title{
ACCESSIBILITY OF UNIVERSAL POSTAL SERVICE ACCORDING TO ACCESS POINTS DENSITY CRITERIA: CASE STUDY OF BJELOVAR-BILOGORA COUNTY, CROATIA
}

\begin{abstract}
Universal service providers have an obligation to provide a minimum required set of postal services - known as universal service obligation. To ensure universal service obligation, regulatory measures (criteria) which service providers must fulfil are often set up. In this paper, a geographical analysis of these criteria is conducted using current regulatory framework in the Republic of Croatia as an example. Based on the framework of the gravity model, accessibility of postal service is presented. The goal of the proposed research is to investigate the application of the gravity model for determining postal service accessibility, with special emphasis on rural areas. To our knowledge, this method has not been used in previous studies to determine accessibility of postal services. The results of the applied model could be used in future planning of access density criteria with various transportation modes.
\end{abstract}

\section{KEY WORDS}

universal postal service; accessibility indicator; gravity model, distance-decay parameter;

\section{INTRODUCTION}

Accessibility of services in postal industry (sector) is viewed through users' possibility to access elements of the postal network. According to the Postal Directive [1], the goal of the universal service obligation (USO) is to provide access to the postal network, where sufficient number of access points should be ensured, in rural and urban areas. Access points are physical elements where postal parcels are deposited to the postal network (letterboxes, post offices, self-serving machines, etc.). The Directive defines the postal network as the system of organization and all types of resources used by the universal service provider(s) (USP) for the purposes, in particular, of:
- the clearance of postal items covered by a universal service obligation from access points throughout the territory;

- the routing and handling of those items from the postal network access point to the distribution center;

- distribution to the addresses shown on items.

A universal model that would ensure access points density is not defined, given that the specific geographic and demographic characteristics vary from one country to another [2]. Different criteria in European countries are analyzed in [3]. The European Regulators Group for Postal Services identified the common criteria which define the density of access points [4]:

- number of postal establishments per locality,

- one postal establishment per number of inhabitants, which could depend on the size of a residential area,

- maximum distance that one must travel to get to the nearest postal establishment,

- maximum (air) distance between neighboring postal establishments,

- minimum number of post offices, providing the USO or a full range of postal services,

- percentage of the population at a certain distance from the postal establishment.

In the Republic of Croatia, the postal market is regulated by the Postal Services Act [5], which is fully compliant with the Directive. Access points density is regulated by the Croatian Regulatory Authority for Network Industries by following conditions [6]:

- one post office operates on average on a maximum surface of $80 \mathrm{~km}^{2}$ (Criterion 1), or

- one post office operates on average for the maximum of 6,000 inhabitants (Criterion 2). 
In addition, the network of postal offices must consist of at least 700 permanent post offices, and the maximum distance between the access points in inhabited areas should not exceed 5,000 m.

Forecasts show a future trend of letter-mail decline but predict an increase in parcel volumes [7]. Because of the many strengths and advantages of the postal industry [8], it is necessary to determine optimal accessibility to postal access points for service users. Special emphasis should be placed on the analysis of the service accessibility in rural areas since provision of the USO in these areas is often not profitable. Studies show that people living in rural areas are more likely to use post offices than those living in urban areas [9]. According to [10], in rural areas post offices influence the reduction of geographical isolation, and with their closure, the population is subjected to social isolation and exclusion. Social and economic importance of the postal system is also expressed in [11].

When organizing the postal network, USPs primarily consider the profitability of their business activities. For service users, accessibility of the collection and delivery is one of several crucial factors [12]. It is also interesting to consider the transformation of the postal network [13] and many possibilities of its future use.

Existing studies of the postal network are focused on access points (post offices) and the area coverage by the network, considering air distances and/or travel times between post offices $[14,15]$. Authors in [16, 17] developed models to determine the optimal number of post offices. Trubint [18] proposed a model for the postal retail segment, where the optimal location of a retail point in the postal network is determined, using geographical information service (GIS). GIS was also used in [19] for analyzing changes in the distance from service users to post offices arising from a reduced number of post offices.

Furthermore, authors in [20] focused on optimization of sorting and transshipment centers, while other studies [21-23] focus on process cost and performance optimization. Lee and Moon [24] have determined mathematical models of a postal logistics network to help network planners and organizers. The concept of accessing the postal network as described in [25] does not include spatial accessibility measures.

Spatial service accessibility is the focus of research in several fields or areas of interest (transport, urban planning and strategic planning, public health etc.). It can often be misunderstood or not well measured, as implied in [26]. Generally, it can be defined as an ability of one to get what one needs, including traveling to places where those needs are met [27]. Accessibility of jobs, services or other points of interest is the key to the development of sustainable transport, spatial planning and other industries [28].
Spatial access to services has been widely discussed in multiple aspects of health care accessibility [29-35]. Accessibility to parks and green surfaces is also widely researched [36-39]. Some studies are focused on determining spatial accessibility in the field of transport [28, 40].

The gravity model (also often referred to as the gravitation model, method or measures) for calculating service accessibility was first introduced by Hansen in 1959 [41] for the purpose of land use planning and was later expanded by Joseph and Bantock [42] for rural health care analysis. This method and its derivates are widely used in various parts of the health care sector. The gravity method determines all potential interactions between the population and service points within a certain distance, and it is one of the most commonly used location-based measures [31]. Combination of distance and supply-demand service component as provided by the gravity model is considered to be the best spatial accessibility measure [43]. The main disadvantage of the gravity model is the distance-decay parameter. Later, the two-step floating catchment area (2SFCA) method was developed as a special type of the gravity model [44] and authors argue that this method overcame the disadvantages related to distance-decay. Variations of the 2SFCA method were also developed [45-49].

Compared to previous research, this study formalizes calculation of spatial accessibility in the postal sector. To our knowledge, spatial accessibility measures in the context of the postal services market have not been discussed before. Since the gravity method presents one of the most commonly used accessibility measures, it is advisable to implement it in the postal sector. Since accessibility of postal access points is determined by regulatory criteria, accessibility indicators obtained from the gravity method provide finer insight into relationships between post offices and the population that they serve. In other words, interactions between post offices and the population that they serve are determined. A comprehensive analysis of distance-decay parameters was conducted, giving valuable insight into values best suited to be implemented when it comes to post office accessibility.

Post service accessibility is analyzed by focusing on each potential population demand point. Post offices are used as the supply, and house numbers as the demand points. This is because post offices offer various types of post services, which is compatible with the USO scope. In future research, the model can be used for calculating a specific service and a specific group of service users. This led to a proposed methodology for selecting the area of research. It was also used to present and interpret data obtained by the application of the model. The contribution of this study is the following: 
- usage of fine spatial resolution data (enabling the calculation of the postal service of each house number);

- a comprehensive analysis of and conclusion about the existing criteria for determining the access points density;

- the application of a potential accessibility measure (gravity model) in the postal sector;

- a discussion on distance-decay parameters for determining postal services accessibility in rural area.

\section{RESEARCH AREA}

As discussed earlier, the problem with the USO lies within its sustainability, especially when service volume is decreasing. The focus of this analysis is to explore service accessibility in rural areas, where the post office network is not as dense as in urban areas. For this purpose, an area of research where the model is applied had to be chosen.

The following steps for selecting the area of research are proposed:

1) decision on the rural/urban area of analysis;

2) application of the OECD (Organization for Economic Cooperation and Development) [50] criteria for rural and/or urban areas and selection of the area based on these findings;

3) analysis of the postal network of the selected area;

4) selecting the area of research for the application of the gravity model in the postal system.
Since the focus of this research are rural areas, the selected area is a rural county in the Republic of Croatia, Bjelovar-Bilogora County. This county has a population of 133,084 , i.e., $6.3 \%$ of the total population of the Republic of Croatia. There is a total of 32 post offices in this county, as well as 54,763 house numbers (Figure 1). The average number of inhabitants per house number in Bjelovar-Bilogora County is 2.2 [51].

The map shows post office locations. A fine resolution of user (demand) points is applied because of the USO. The universal nature of any service (post, electric, Internet broadband, etc.) implies its necessity to cover the entire area of a country and places an obligation on the USP (as well as the government) to ensure service accessibility to all citizens. Determining service accessibility of each house number gives a detailed insight into the state of the postal network. It also enables the analysis of possible gaps in the provision of the service.

\section{ACCESS POINT DENSITY CRITERIA}

An analysis of the postal office network was carried out, according to Criterion $1\left(80 \mathrm{~km}^{2}\right.$ generate a $5 \mathrm{~km}$ air distance radius centered at the post office location). This analysis can be presented through the following steps:

- for each house number and post office point, $x$ and $y$ coordinates are given;

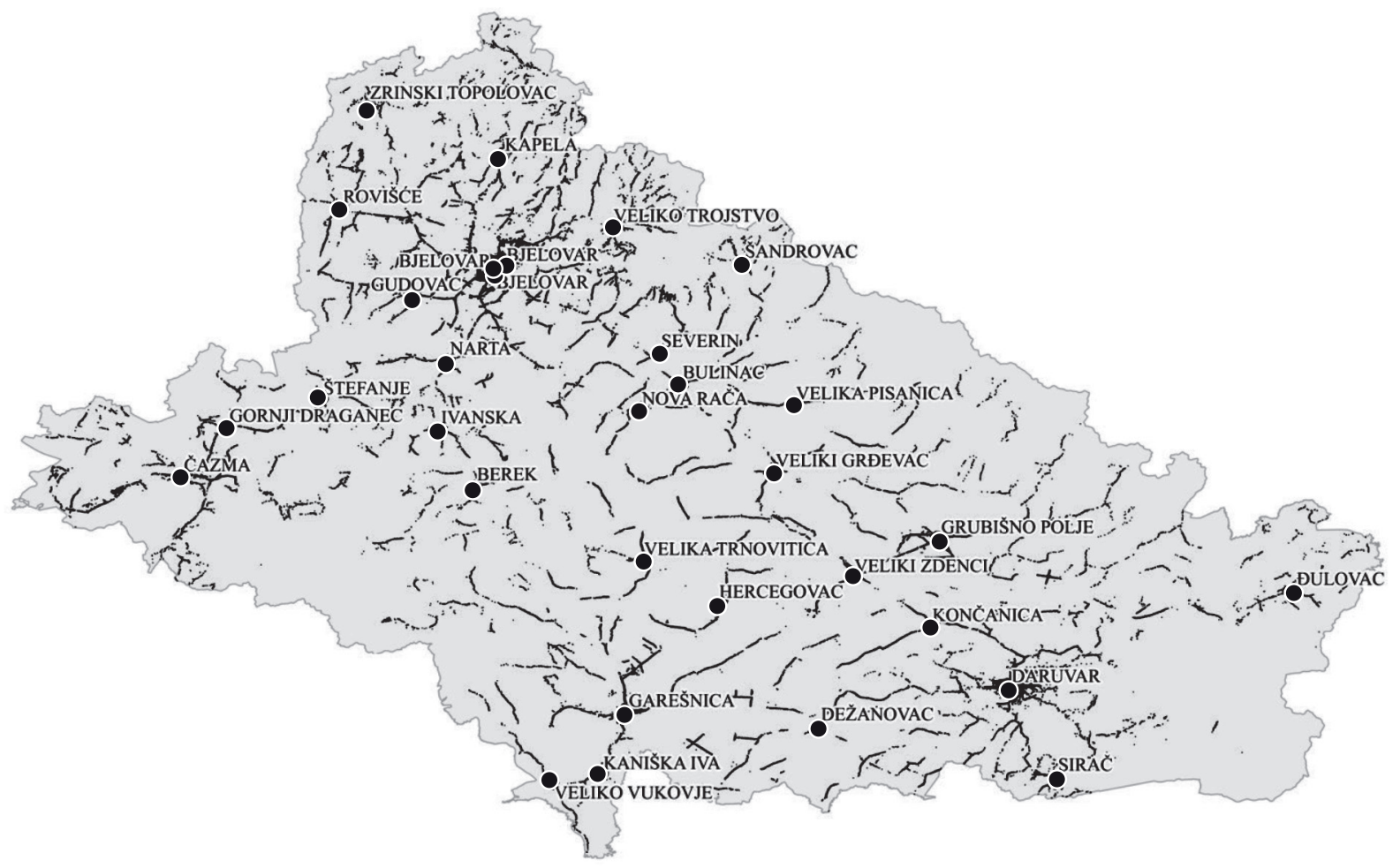

Figure 1 - Geographic location of post offices in Bjelovar-Bilogora County 
- using Expression 1 that calculates the Euclidean distance between two points, it is possible to calculate the distance between all house numbers and post offices in the analyzed area;

- by limiting the radius of analysis to $5 \mathrm{~km}$, starting from the post office, it is possible to calculate the number of inhabitants that one post office serves.

$d_{P O, H N}=\sqrt{\left(x_{P O}-x_{H N}\right)^{2}+\left(y_{P O}-y_{H N}\right)^{2}}$

where $d_{P O, H N}$ is the Euclidean distance between a house number and a post office, $\left(x_{P O}, \mathrm{y}_{P O}\right)$ are geographic coordinates of post offices and $\left(x_{H N}, y_{H N}\right)$ are geographic coordinates of house numbers.

The results of the analysis are shown in Table 1 . It is evident that post offices in the city of Bjelovar serve the most inhabitants. However, most post offices work for less than 5,000 inhabitants.

Table 1 shows the difference to the total number of the population in Bjelovar-Bilogora County $(60,942)$. This means that Criterion 1 accounts for more inhabitants than there are actually living in the county. This difference is generated because post office covers all inhabitants living within a $5 \mathrm{~km}$ distance. In the areas where more than one post office is located within 5 $\mathrm{km}$, some parts of the population are counted more than once. As a result, the number of inhabitants served by post offices increases. This is particularly evident in cities.

The following analysis shows the results obtained by applying Criterion 2 . This analysis can be presented through the following steps:

- the distance between all house numbers and post offices is known;
- starting from the location of a post office, all house numbers are searched, with a maximum of 6,000 inhabitants;

- the distance to the location where post office fulfils Criterion 2 is generated.

Table 2 shows distances to the nearest post offices. The post offices that meet the criteria of working for a maximum of 6,000 inhabitants are three post offices operating in Bjelovar (criteria fulfilled at about $1 \mathrm{~km}$ distance). The post office where this criterion is met at the longest distance is the one in Đulovac (about 15 $\mathrm{km})$. For the 32 existing post offices of the county, the average distance is $6.45 \mathrm{~km}$.

Shortcomings generated from the conducted analysis

Several disadvantages have been identified in this approach of planning post office density. First, the area where 6,000 inhabitants are to be restricted is not provided (since it is exclusive to the criterion that one office covers an area of $80 \mathrm{~km}^{2}$ ). The second problem is the overlapping of service areas, where one office operates at the same distance until it reaches a maximum of 6,000 inhabitants. It is evident that criteria set in such a way do not account for the differences in area coverage and the overlapping of the population (Table 1).

These shortcomings should be considered by the authorized bodies in charge of its implementation. If the criteria do not take service demand into consideration, but only the network organization from the service provider perspective, then other models for determining access points density should be considered.

Table 1 - Number of inhabitants served by one post office, applying Criterion 1

\begin{tabular}{|c|l|c|c|l|c||}
\hline \multicolumn{1}{|c|}{$\begin{array}{c}\text { Post office } \\
\text { (residential area) }\end{array}$} & No of inhabitants & \multicolumn{1}{c|}{$\begin{array}{c}\text { Post office } \\
\text { (residential area ) }\end{array}$} & No of inhabitants \\
\hline \hline 1. & Bjelovar & 23,155 & 17. & Velika Pisanica & 2,893 \\
\hline 2. & Bjelovar & 22,887 & 18. & Nova Rača & 2,998 \\
\hline 3. & Bjelovar & 22,922 & 19. & Bulinac & 3,733 \\
\hline 4. & Zrinski Topolovac & 1,819 & 20. & Severin & 4,802 \\
\hline 5. & Kapela & 5,126 & 21. & Garešnica & 5,577 \\
\hline 6. & Rovišće & 3,608 & 22. & Veliko Vukovje & 1,538 \\
\hline 7. & Veliko Trojstvo & 6,279 & 23. & Kaniška Iva & 2,061 \\
\hline 8. & Šandrovac & 1,905 & 24. & Hercegovac & 2,677 \\
\hline 9. & Ivanska & 2,996 & 25. & Velika Trnovitica & 1,887 \\
\hline 10. & Berek & 2,741 & 26. & Grubišno Polje & 4,657 \\
\hline 11. & Čazma & 27. & Veliki Zdenci & 3,225 \\
\hline 12. & Gornji Draganec & 28 & Daruvar & 11,689 \\
\hline 13. & Štefanje & 3,843 & 29. & Končanica & 2,776 \\
\hline 14. & Narta & 2,264 & 30. & Dežanovac & 2,422 \\
\hline 15. & Gudovac & 3,824 & 31. & Đulovac & 1,639 \\
\hline 16. & Veliki Grđevac & 12,234 & Sirač & 2,862 \\
\hline Population in total & 2,776 & 180,706 & \\
\hline Difference to total number of population in county & 47,642 & \\
\hline
\end{tabular}


Table 2 - Distances to nearest post office, applying Criterion 2

\begin{tabular}{|c|c|c|c|c|c|}
\hline & $\begin{array}{c}\text { Post office } \\
\text { (residential area) }\end{array}$ & Distance $[\mathrm{km}]$ & & $\begin{array}{c}\text { Post office } \\
\text { (residential area) }\end{array}$ & Distance $[\mathrm{km}]$ \\
\hline 1. & Bjelovar & 1 & 17. & Velika Pisanica & 7.66 \\
\hline 2. & Bjelovar & 1.15 & 18. & Nova Rača & 6.99 \\
\hline 3. & Bjelovar & 1.13 & 19. & Bulinac & 6.74 \\
\hline 4. & Zrinski Topolovac & 9.09 & 20. & Severin & 5.89 \\
\hline 5. & Kapela & 5.49 & 21. & Garešnica & 5.37 \\
\hline 6. & Rovišće & 6.86 & 22. & Veliko Vukovje & 9.25 \\
\hline 7. & Veliko Trojstvo & 4.86 & 23. & Kaniška Iva & 7.57 \\
\hline 8. & Šandrovac & 7.81 & 24. & Hercegovac & 7.22 \\
\hline 9. & Ivanska & 7.54 & 25. & Velika Trnovitica & 7.72 \\
\hline 10. & Berek & 8.73 & 26. & Grubišno Polje & 6.19 \\
\hline 11. & Čazma & 6.08 & 27. & Veliki Zdenci & 6.08 \\
\hline 12. & Gornji Draganec & 695 & 28 & Daruvar & 1.25 \\
\hline 13. & Štefanje & 8.15 & 29. & Končanica & 6.05 \\
\hline 14. & Narta & 5.86 & 30. & Dežanovac & 7.89 \\
\hline 15. & Gudovac & 3.98 & 31. & Đulovac & 15.04 \\
\hline 16. & Veliki Grđevac & 7.67 & 32. & Sirač & 7.14 \\
\hline \multicolumn{3}{|c|}{ Average distance } & \multicolumn{3}{|c|}{$6.45 \mathrm{~km}$} \\
\hline
\end{tabular}

\section{UNIVERSAL POSTAL SERVICE ACCESSIBILITY}

Gravity-based models are frequently used in the literature to describe spatial accessibility and to determine service accessibility in a specific area. Hansen's gravity model was first presented in 1959, expressed by 2 [41]:

$$
\begin{aligned}
& A_{i}=\sum_{j=1}^{n} \frac{S_{j}}{d_{i j}^{\beta}} \text { for each } d_{i j} \leq d_{\max } \\
& A_{i}=0 \text { for } d_{i j} \geq d_{\max }
\end{aligned}
$$

where $A_{i}$ is the accessibility indicator of demand point $i, S_{j}$ is service capacity of the service provider on location $j$ (number of post offices within the area), $d_{i j}$ is air distance between points $i$ and $j$, and $\beta$ is the distance-decay parameter.

The distance-decay parameter is one of the biggest deficiencies of the gravity model [52], because it is not easy to determine. It shows user's willingness to travel to a service, where different values should be used in urban or rural areas. The value of the distance-decay parameter is a subject of discussions in the literature, considering there are no generally accepted values used. Luo and Wang [44] tested different parameter values and compared them to travel times. The smaller the parameter, the longer people are willing to travel to reach certain services.

Since real data of service usage are often unavailable, authors consider different values of the distance-decay parameter, already defined in the literature [44] . Hansen [41] found that the values can range from $0.5-3$, depending on the purpose of the trip: traveling to school or a shopping destination (2.0), social travel (1.1), traveling to the workplace (0.9).

Condition $d_{i j} \leq d_{\max }$ depicts the catchment area where service accessibility is calculated. The catchment area in this study is limited to the boundaries of Bjelovar-Bilogora County.

Figure 2 shows how accessibility indicator values change depending on the distance and for different $\beta$ parameters (applying Expression 2). For up to $1 \mathrm{~km}$ distance, it is evident that service accessibility indicator decreases rapidly.

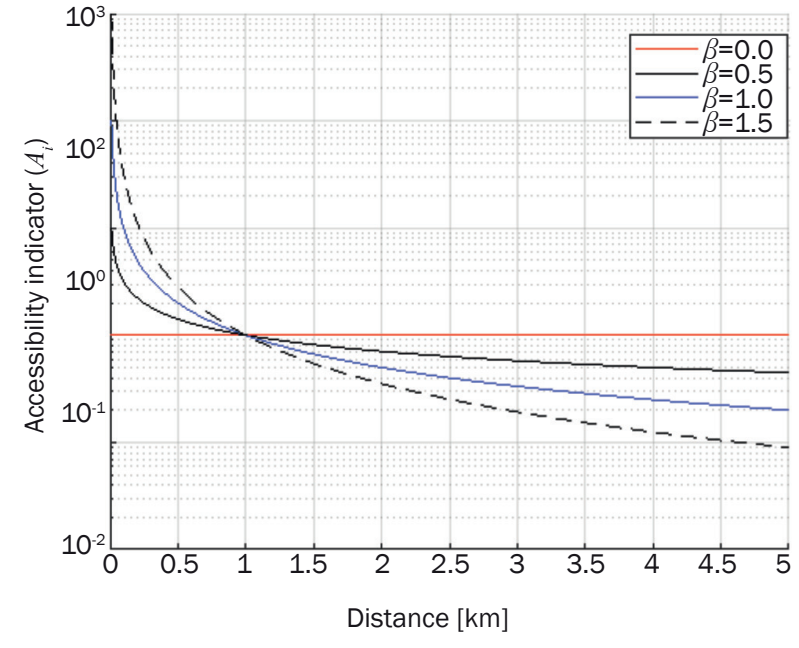

Figure 2 - Influence of distance-decay parameter $\beta$ on accessibility indicator $A_{i}$ 
The gravity model was used only for modelling the supply, not the demand of a service. This is evident in Expression 2. Later, the model was expanded [42] to include the demand for a service, as shown in Expression 3:

$A_{i}=\sum_{j=1}^{n} \frac{S_{j}}{d_{i j}^{\beta} V_{j}} ; \quad V_{j}=\sum_{k=1}^{n} \frac{p_{i}}{d_{i j}^{\beta}}$ for each $d_{i j} \leq d_{\max }$ $A_{i}=0$ for $d_{i j} \geq d_{\max }$

where $A_{i}$ is the accessibility indicator of demand point $i, S_{j}$ is service capacity of the service provider on location $j$ (number of post offices within the area), $V_{j}$ is demand of the population for a service on location $j$, while $p_{i}$ is the number of house numbers on location $i$ within the catchment area.

In the following section, different values of the accessibility indicator are discussed, using the distance-decay parameters in the range of $0.5-3$ (with a 0.5 increment), as Hansen suggested. The goal is to study appropriate values of the distance-decay parameters for postal service accessibility.

To compare the results, a data classification method has been adopted for the interpretation of the results. The equal intervals method has been selected for the interpretation of the results, because of its relative simplicity in implementation and interpretation. This method divides the data into equal intervals, where the number of ranges is defined. Six ranges of the accessibility indictor data have been generated (C1, C2, C3, C4, C5 and C6). C1 category indicates the lowest accessibility indicator values (marked light grey on the map), while C6 category indicates the highest accessibility indicator scores (marked dark grey on the map), as shown on Figure 3. Six categories were chosen to reflect the distances to post offices (as

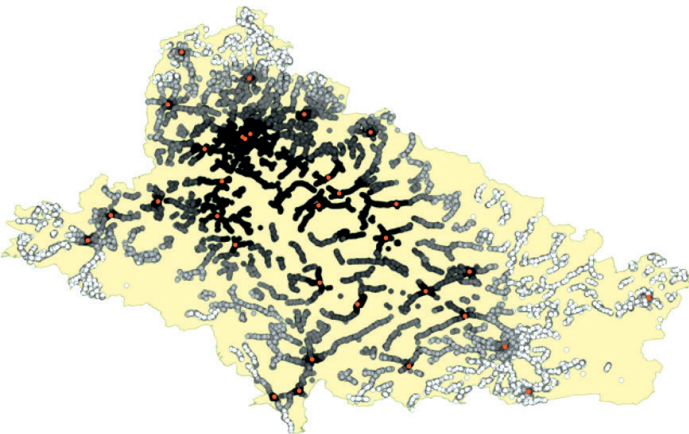

a) $\beta=0.5$

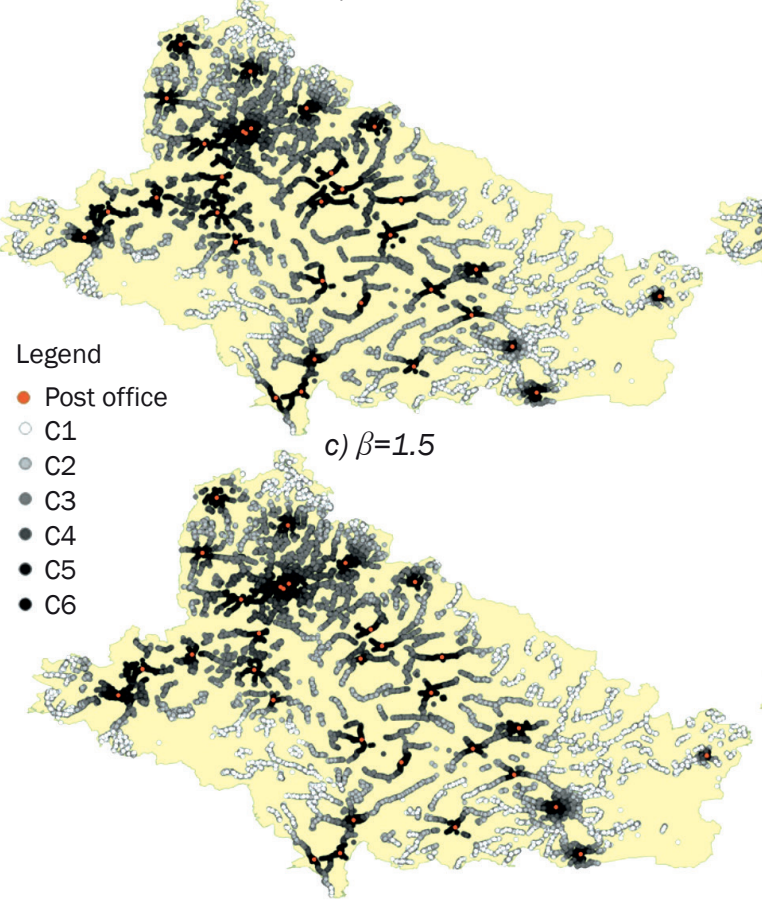

e) $\beta=2.5$

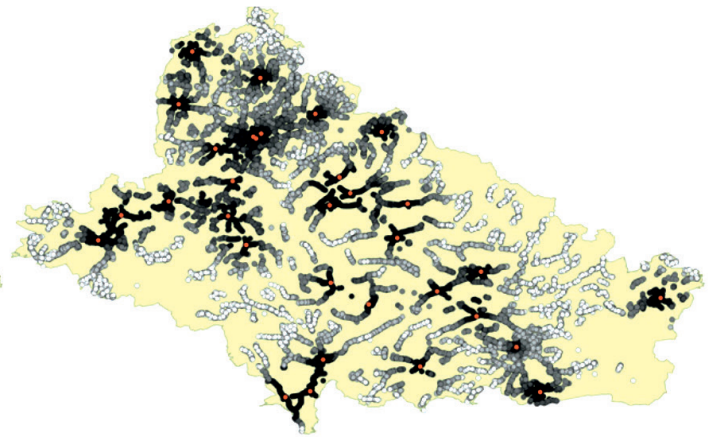

b) $\beta=1$

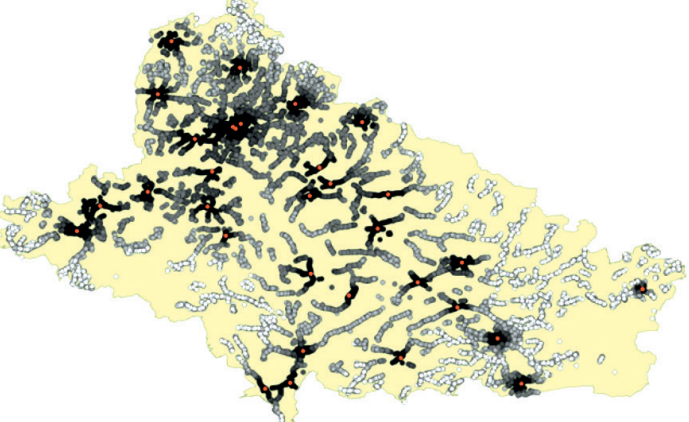

d) $\beta=2$

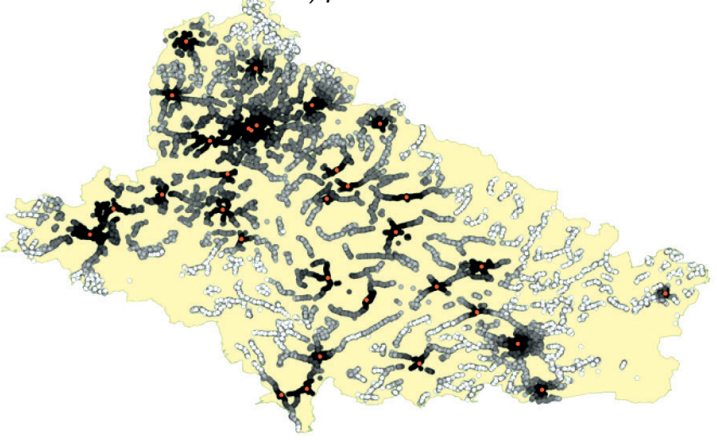

f) $\beta=3$

Figure 3 - Post service accessibility indicators in Bjelovar-Bilogora County with multiple distance-decay parameters 
Table 3 - Average distances [km] for different distance decay parameters

\begin{tabular}{||l|c|c|c|c|c|c||}
\hline & C1 & C2 & C3 & C4 & C5 & C6 \\
\hline \hline$\beta=0.5$ & 5.43 & 3.47 & 2.86 & 2.74 & 2.18 & 0.67 \\
\hline$\beta=1$ & 5.95 & 3.80 & 3.11 & 2.65 & 1.39 & 0.45 \\
\hline$\beta=1.5$ & 6.11 & 3.89 & 3.43 & 2.24 & 1.24 & 0.44 \\
\hline$\beta=2$ & 6.27 & 4.05 & 3.35 & 2.09 & 1.16 & 0.42 \\
\hline$\beta=3$ & 6.32 & 4.11 & 3.26 & 2.05 & 1.17 & 0.43 \\
\hline \hline
\end{tabular}

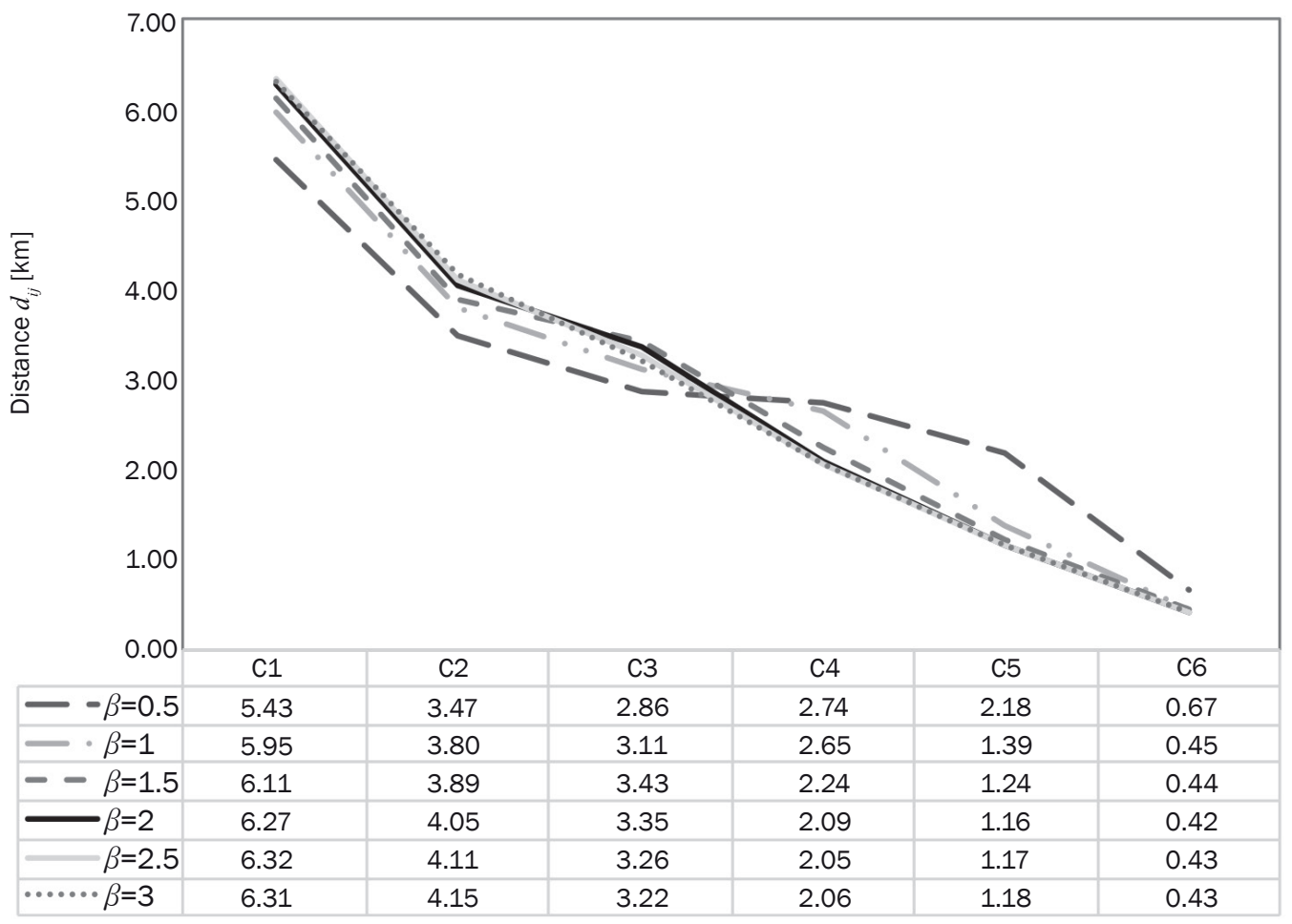

Figure 4 - Distance values for post service accessibility indicators, by category type

shown in Table 2). This will allow the analysis of distinctions in the accessibility indicator values across the county.

Figure 3 shows post service accessibility indicators, using different distance-decay parameters (0.5-3; with a 0.5 increment). The differences in spatial accessibility of the postal service are evident, especially at smaller distances. If $\beta=0.5$ is considered, it is evident that there are service points (post offices) with lower values of the accessibility indicator. House numbers located around exterior service points have lower service accessibility than those located in the inner part of the county.

When considering other ranges of the distance-decay parameter, minimum distinctions are evident, mainly around service points. It is interesting to notice that certain house numbers (in the far north, east and south-west part of the county) have minimum service accessibility. For these house numbers, post offices are inaccessible (according to the regulatory Criterion 1).
The average distances for different distance-decay parameters are shown in Table 3.

According to Criterion 1, C1 category of accessibility indicator values is inaccessible to the population (because the distance to service points is larger than $5 \mathrm{~km}$ ). Figure 4 shows how the distance changes in respect to various distance-decay parameters.

It is evident in Figure 4 that some results are congruent. This can primarily be noted for $\beta=2, \beta=2.5$ and $\beta=3$ values. It can be concluded that postal service accessibility calculated using these $\beta$ values will not differ significantly. Something similar occurs with $\beta=1.5$ values, with minor deviations around the trend line.

Figure 5 gives a detailed analysis of accessibility indicator values obtained by $\beta=0.5, \beta=1$ and $\beta=1.5$ exponents. These results have been further analyzed since variations in the trend line for these values are evident. Distances between each category are indicated, describing variations for each accessibility indicator category. 


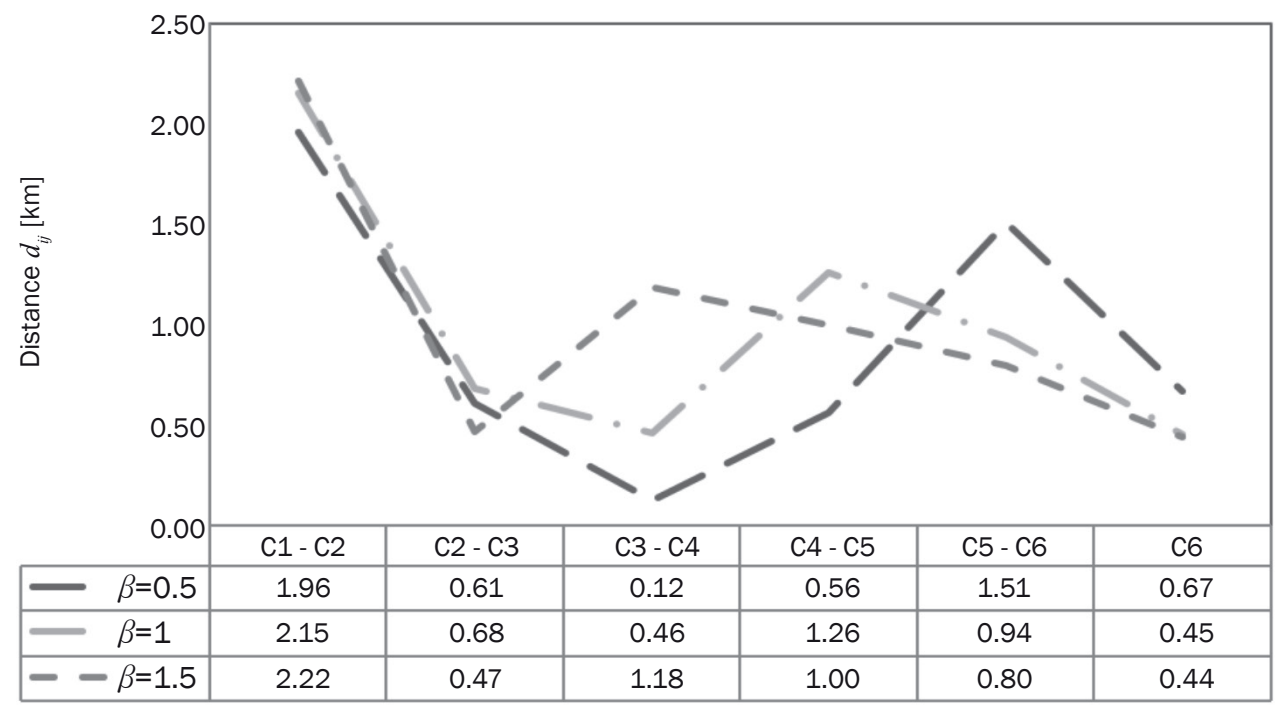

Figure 5 - Variations in distance for accessibility indicator category

Figure 5 shows the biggest variations in the distance in C1 - C2 (2.22 km for $\beta=1.5)$ and C5 - C6 (1.51 $\mathrm{km}$ for $\beta=0.5)$. It can generally be stated that for all $\beta$ values, the $\mathrm{C} 1$ - C2 category shows the greatest increase in distance. This can be characterized as a method, especially since it is common regardless of the given $\beta$ value. A shift between categories can be noted, where with $\beta=0.5$ values the highest increase is in the $\mathrm{C5}-\mathrm{C} 6$ range; with $\beta=1$ is in $\mathrm{C} 4-\mathrm{C} 5$; and with $\beta=1.5$ is in the $\mathrm{C} 3-\mathrm{C} 4$ range.

\section{RESULTS AND DISCUSSION}

The gravity model applied in this research was modelled with catchment area concurrent with the border of one county in the Republic of Croatia, predominantly rural area. Analysis showed that certain house numbers have accessibility that is not in line with the set regulatory criteria (located further than $5 \mathrm{~km}$ from their nearest post office). Distance-decay parameters were simulated in the range of $0.5-3$ (with a 0.5 increment). Accessibility indicators obtained by $\beta=1.5-3$ exponents result in having similar distances. It can be concluded that when using $\beta$ values in this range, similar results will be generated. For this reason, an additional analysis using $\beta=0.5-1.5$ exponents was conducted. A shift in distance categories was noted, leading to the conclusion that different values could be used for modelling access to post offices using various transport modes. This provides opportunities for further research of post service accessibility using the gravity model with various transport modes.

If Figures 4 and 5 are considered, results can be further explored when modelling access to postal services with transportation modes. Several transportation modes could be adequate for implementation, with focus on rural areas: walking, cycling and usage of personal vehicles (or public transportation). Since post offices are often located at the center of residential areas, the walking mode can be easily used to determine service access at smaller distances. Cycling is also preferable to use for small to medium distances, especially in communities lacking organized public transport. The personal vehicle transportation mode is appropriate to use for medium to longer distances, as it provides simplicity in the movement of the population. Public transport could also be considered, bearing in mind that it is usually not well (frequently) organized in smaller/rural communities.

To model access to post offices using various transport modes, users' willingness to travel to post offices should be considered. This is generally expressed in distance or travel times needed in order to reach a service. According to different studies, travel times and distances that people are willing to cross to reach different services in different countries vary [53-58]. This is determined by the characteristics of the research area, habits and specificities of the population, etc. It is to be assumed that people living in rural areas usually travel longer to reach specific services.

Based on the existing studies, Table 4 shows proposed travel times and distance values users are willing to cross to reach a post office.

If post service accessibility is to be considered for pedestrians, it would be advisable to consider model behavior which allows modelling of accessibility for demand points closest to post offices. In other words, the highest accessibility index category $\mathrm{C} 6$ should be considered. Table 3 shows that the distance-decay parameter value of $\beta=0.5$ would be most appropriate. It can be assumed that other categories are inaccessible for pedestrians. For cyclists, the average travel distances are longer, so accessibility index categories of C5 and C6 should be considered. The gravity model with $\beta=1$ would be appropriate for this transportation mode. Since travel distances for personal vehicles and public 
Table 4 - Average travel time and distance to reach post office

\begin{tabular}{||l|c|l||}
\hline \multicolumn{1}{|c|}{ Transportation mode } & {$[\mathrm{min}]$} & {$[\mathrm{km}]$} \\
\hline \hline Pedestrians & 10 & 0,8 \\
\hline Cycling & 10 & 2,5 \\
\hline $\begin{array}{l}\text { Personal vehicle / } \\
\text { public transportation }\end{array}$ & 8,5 & 5,64 \\
\hline
\end{tabular}

transportation further increase, accessibility categories of $\mathrm{C} 4, \mathrm{C} 5$ and $\mathrm{C} 6$ can be taken into account. In this case, model with $\beta=1.5$ exponent could be found appropriate.

\section{CONCLUSION}

The universal nature of the postal service implies its accessibility to the entire population of a country. This is usually defined and carried out by regulations or certain criteria that the universal service providers must meet to ensure service accessibility. These criteria are often not well-defined and do not consider the real state or organization of the postal network.

The analysis of the current state of the postal network showed certain disadvantages of these criteria, primarily evident in overpopulating the network. Previous studies on universal service in the postal system did not include the use of methods for determining the service accessibility indicator. In this research, the accessibility indicator was introduced to the postal system and calculated. This led to a detailed insight into the accessibility of the postal service, considering the distances between the point of demand (house number) and the point of supply (post office).

This approach for determining universal service accessibility can have several potential applications. On the one hand, a universal service provider can use this model and insights for conducting a quality analysis of the status of the postal office network and accessibility (or inaccessibility) of access points to the population of a certain area. This can enable the USP to dynamically facilitate changes in the organization of the post office network in order to gain better access to service users. Regulatory bodies that oversee the fulfilment of the universal service obligation can use the model as a tool for better controlling service accessibility. However, since these are estimates, additional research should be conducted in the future.

\section{Dr. Sc. KATARINA MOSTARAC ${ }^{1}$}

E-pošta: katarina.mostarac@fpz.hr

Dr. sc. ZVONKO KAVRAN. ${ }^{1}$

E-pošta: zvonko.kavran@fpz.hr

Dr. sc. ESTERA RAKIĆ ${ }^{2}$

E-pošta: estera.rakic@posta.hr

${ }^{1}$ Sveučilište u Zagrebu, Fakultet prometnih znanosti

Vukelićeva 4, 10000 Zagreb, Hrvatska

2 Hrvatska pošta d.d.

Jurišićeva 13, 10000 Zagreb, Hrvatska

\section{DOSTUPNOST UNIVERZALNE POŠTANSKE USLUGE PREMA KRITERIJIMA GUSTOĆE PRISTUPNIH TOČAKA: STUDIJA SLUČAJA BJELOVARSKO- BILOGORSKE ŽUPANIJE, HRVATSKA}

\section{SAŽETAK}

Davatelji univerzalnih us/uga imaju obvezu pružanja skupine minimalno potrebnih poštanskih usluga - poznatih kao obveza univerzalne usluge. Kako bi se osigurala obveza univerzalne usluge, često se uspostavljaju regulatorne mjere (kriteriji) koje davatelji usluga moraju ispuniti. U ovom radu provodi se geografska analiza navedenih kriterija, uz primjenu postojećeg regulatornog okvira u Republici Hrvatskoj. Na temelju gravitacijskog modela, prikazana je dostupnost poštanskih usluga. Cilj provedenog istraživanja jest istražiti primjenu gravitacijskog modela za određivanje dostupnosti poštanskih usluga, s posebnim naglaskom na ruralna područja. Prema našim spoznajama, u prethodnim istraživanjima ova metoda nije korištena kako bi se odredila dostupnost poštanskih usluga. Rezultati primijenjenog modela mogli bi se koristiti u budućem planiranju kriterija gustoće pristupnih točaka koristeći različite modove transporta.

\section{KLUČNE RIJEČI}

univerzalna poštanska usluga; pokazatelj dostupnosti; gravitacijski model; parametar propadanja s udaljenosti;

\section{REFERENCES}

[1] European Union. Directive 2008/6/EC of the European Parliament and of the Council of 20 February 2008 amending Directive 97/67/EC with regard to the full accomplishment of the internal market of Community postal services. Strasbourg: European Parliament and Council; 2008.

[2] CERP. Implementation Guide, Universal Service. CERP PL 2009/2 Doc 13 Rev.1, 2009.

[3] International Post Corporation (IPC). Postal Regulatory Database. Country Directory. Brussels, Belgium, 2014.

[4] European Regulators Group for Postal Services. Report on the quality of service, consumer protection and complaint handling - an analysis of trends. ERGP (16) 37, December 2016.

[5] Republic of Croatia. [Law on Postal Services]. Official Gazette. 2013, 144/12, 153/13, 78/15. Croatian.

[6] Croatian Regulatory Authority for Network Industries. [Ordinance on the Provision of Universal Service]. Official Gazette, 2013, 41/13. Croatian.

[7] Faculty of Transport and Traffic Sciences, Deloitte. [Strategy of postal service market development in the Republic of Croatia by the 2020]. Ministry of the Sea, Transport and Infrastructure, 2014. Croatian.

[8] Microsoft. Digital Opportunities for the Postal Industry. A Microsoft White Paper, 2007.

[9] NERA Economic Consulting: Access to Postal Services, A final report for Postcomm, 2007.

[10] Langford M, Higgs G. Accessibility and Public Service Provision: Evaluating the Impacts of the Post Office Network Change Programme in the UK. Transactions of the Institute of British Geographers. 2010;35(4): 585-601. Available from: doi:10.1111/j.1475- 
5661.2010.00394.x [Accessed 13 September 2017]

[11] Accenture. International Postal Liberalization - Comparative Study of US and Key Countries; 2008.

[12] RAND Europe. Study on Appropriate Methodologies to Better Measure Consumer Preference for Postal Services. Final report, 2011.

[13] Boston Consulting Group. Focus on the Future, Building a new Compelling Position for the Post, International Post Corporation, 2012.

[14] Madlenak R, Madlenakova L, Štefunko J. The Variant Approach to the Optimization of the Postal Transportation Network in the Conditions of the Slovak Republic. Transport and Telecommunications. 2015;16(3): 237-245. Available from: doi:10.1515/ttj-2015-0022 [Accessed 15 June 2017].

[15] Šarac D, Kopić M, Mostarac K, Kujačić M. Jovanović B. Application of Set Covering Location Problem for Organizing the Public Postal Network. Promet - Traffic \& Transportation. 2016;28(4): 403-413. Available from: doi:10.7307/ ptt.v28i4.1962 [Accessed 20 January 2017].

[16] Blagojević M, Šelmić M, Macura D, Šarac D. Determining the Number of Postal Units in the Network - Fuzzy Approach, Serbia Case Study. Expert Systems with Applications. 2013;40(10): 4090-4095. Available from: doi:10.1016/j.eswa.2013.01.038 [Accessed 20 January 2017].

[17] Šarac D, Kujačić M, Dumnić S. Determination Number of Nodes in the Postal Logistics Network of Public Postal Operator. In: Proceedings of $1^{\text {st }}$ Logistics International Conference, 28 - 30 November 2013, Belgrade, Serbia; p. 20-25.

[18] Trubint N. A GIS Application to Explore Postal Retail Outlet Locations. Promet - Traffic \& Transportation. 2012;24(2): 161-168. Available from: doi:10.7307/ ptt.v24i2.288 [Accessed 20 January 2017].

[19] Higgs G, Langford M. Investigating the Validity of Rural-Urban Distinctions in the Impacts of Changing Service Provision: The Example of Postal Service Reconfiguration in Wales. Geoforum. 2013;47: 53-64. Available from: doi:10.1016/j.geoforum.2013.02.011 [Accessed 16 October 2017].

[20] Jablonsky J, Lauber J. A Time - Cost Optimization of the National Postal Distribution Network. Journal of Multi- Criteria Decision Analysis. 1999;8: 5156. Available from: doi:10.1002/(SICI)1099-1360 (199901)8:1<51::AID-MCDA229>3.0.CO;2-B [Accessed 14 September 2016].

[21] Lisec A, Rihter A. Logistical Operation in Postal Logistics Centres. Logistics and Sustainable Transport. 2007;1(2): 1-12.

[22] Kujačić M, Nikoličić S, Jovanović B, Mirčetić D. Logistical Performance in Postal Logistics Centres. In: Proceedings of $1^{\text {st }}$ Logistics International Conference, 28-30 November 2013, Belgrade, Serbia; p. 209-214.

[23] Mirčetić D, Nikoličić S, Maslarić M, Stanojević M. Simulation as a Tool for Extracting Key Performance Parameters in Postal Logistics Centres. In: Proceedings of $2^{\text {nd }}$ Logistics International Conference, 21-23 May 2015, Belgrade, Serbia; p. 210-215.

[24] Lee J-H, Moon I. A Hybrid Hub-and-Spoke Postal Logistics Network with Realistic Restrictions: A Case Study of Korea Post. Expert Systems with Applications. 2014;41(11): 5509-5519. Available from: doi:10.1016/j.eswa.2014.02.027 [Accessed 9 January 2018].

[25] Šarac D, et al. Postal Network Access and Service Quality: Expectation and experience in Serbia. Utilities Policy. 2017;48: 69-75, Available from: doi:10.1016/j. jup.2017.09.004 [Accessed 20 May 2018].

[26] Geurs KT, Wee B. Accessibility Evaluation of LandUse and Transport Strategies: Review and Research Direction. Journal of Transport Geography. 2004;12: 127-140. Available from: doi:10.1016/j.jtrangeo.2003.10.005 [Accessed 17 January 2018].

[27] Levinson David M, Krizek KJ. Access to Destinations. $1^{\text {st }}$ ed. United Kingdom: Elsevier Science; 2005.

[28] Ford AC, Barr SL, Dawson RJ, James P. Transport Accessibility Analysis Using GIS: Assessing Sustainable Transport in London. International Journal of GeoInformation. 2015;4(1): 124-149. Available from: doi:10.3390/ijgi4010124 [Accessed 16 September 2017].

[29] Luo W. Using GIS-based Floating Catchment Method to Assess Areas with Shortage of Physicians. Health and Place. 2004;10: 1-11. Available from: doi:10.1016/ S1353-8292(02)00067-9 [Accessed 15 May 2017].

[30] Fortney J, Rost K, Warren J. Comparing Alternative Methods of Measuring Geographic Access to Health Services. Health Services and Outcomes Research Methodology. 2000;1(2): 173-184.

[31] Guagliardo MF. Spatial Accessibility of Primary Care: Concepts, Methods and Challenges. International Journal of Health Geographics. 2004;3(3). Available from: doi:10.1186/1476-072X-3-3 [Accessed 13 March 2017].

[32] Wang L. Analysing Spatial Accessibility to Health Care: A Case Study of Access by Different Immigrant Groups to Primary Care Physicians in Toronto. Annals of GIS. 2011;17(4): 237-251.

[33] Cheng Y, Wang JE, Rosenberg MW. Spatial Access to Residential Care Resources in Beijing, China. International Journal of Health Geographics. 2012;11(32). Available from: doi:https://doi.org/10.1186/1476072X-11-32 [Accessed 15 June 2017].

[34] Ye H, Kim H. Measuring Spatial Health Care Disparity Using a Network-based Accessibility Index Method in a GIS Environment: A case study of Hillsborough County, Florida. International Journal of Geospatial and Environmental Research. 2014;1(1): 1-21.

[35] Cai E, Liu Y, Jing Y, Zhang L, Li J, Yin C. Assessing Spatial Accessibility of Public and Private Residential Aged Care Facilities: A case Study in Wuhan, Central China. International Journal of Geo-Information. 2017;6(304). Available from: doi:10.3390/ijgi6100304 [Accessed 17 January 2018].

[36] Zhang X, Lu H, Holt JB. Modelling Spatial Accessibility to Parks: A National Study. International Journal of Health Geographics. 2001;10(31). Available from: doi:10.1186/1476-072X-10-31 [Accessed 20 November 2016].

[37] Comber A, Brundson C, Green E. Using a GIS-based network analysis to determine urban greenspace accessibility for different ethnic and religious groups. Landscape and Urban Planning. 2008;86: 102-114. Available from: doi:10.1016/j.landurbplan.2008.01.002 [Accessed 8 January 2017]. 
[38] Dai D. Racial/Ethnic and Socioeconomic Disparities in Urban Green Space Accessibility: Where to Intervene? Landscape and Urban Planning. 2011;102: 234-244. Available from: doi:10.1016/j.landurbplan. 2011.05.002 [Accessed 16 November 2017].

[39] Lee G, Hong I. Measuring Spatial Accessibility in the Context of Spatial Disparity Between Demand and Supply of Urban Park Service. Landscape and Urban Planning. 2013;119: 85-90. Available from: doi:10.1016/j. landurbplan.2013.07.001 [Accessed 16 March 2018].

[40] Langford M, Fry R, Higgs G. Measuring Transit System Accessibility Using a Modified Two-step Floating Catchment Technique. International Journal of Geographical Information Science. 2012;26(2): 193-214. Available from: doi:10.1080/13658816.2011.574140 [Accessed 9 January 2017].

[41] Hansen WG. How Accessibility Shapes Land Use. Journal of the American Institute of Planners. 1959;2(35): 73-76. Available from: doi:10.1080/ 01944365908978307 [Accessed 5 May 2017].

[42] Joseph AE, Bantock PR. Measuring Potential Physical Accessibility to General Practitioners in Rural Areas: A Method and Case Study. Social Science \& Medicine. 1982;16: 85-90. Available from: doi:10.1016/02779536(82)90428-2 [Accessed 1 May 2017].

[43] Yang DH, George R, Mullner R. Comparing GIS-based Methods of Measuring Spatial Accessibility to Health Services, Journal of Medical Systems. 2005;30(1): 2332. Available from: doi:10.1007/s10916-006-7400-5 [Accessed 16 March 2017].

[44] Luo W, Wang F. Measures of Spatial Accessibility to Health Care in GIS Environment: Synthesis and a Case Study in the Chicago Region. Environment and Planning B: Urban Analytics and City Science. 2003;30: 865-884. Available from: doi:10.1068/b29120 [Accessed 8 March 2017].

[45] Luo W, Qi Y. An Enhanced Two-step Floating Catchment Area (E2SFCA) Method for Measuring Spatial Accessibility to Primary Care Physicians. Health and Place. 2009;15: 1100-1107. Available from: doi:10.1016/j.healthplace. 2009.06.002 [Accessed 20 February 2017].

[46] Ngamini Ngui A, Apparicio P. Optimizing the two-step Floating Catchment Area Method for Measuring Spatial Accessibility to medical Clinics in Montreal. BMC Health Services Research. 2011;11(166). Available from: doi:10.1186/1472-6963-11-166 [Accessed 16 September 2017].

[47] Wan N, Zhan FB, Zou B, Chow E. A Relative Spatial Access Approach for Analyzing Potential Spatial Access to Colorectal Cancer Service in Texas. Applied Geography. 2012;32: 291-299. Available from: doi:10.1016/j. apgeog.2011.05.001 [Accessed 9 October 2017].

[48] Mao L, Nekorchuk D. Measuring spatial accessibility to healthcare for populations with multiple transportation modes. Health and Place. 2013;24: 115-122. Available from: doi:10.1016/j.healthplace.2013.08.008 [Accessed 16 September 2017].

[49] Dony CC, Demelle EM, Demelle EC. Re-conceptualizing Accessibility to Parks in Multi-Modal Cities: A Variable-width Floating Catchment Area (VFCA) method. Landscape and Urban Planning. 2015;143: 90-99. Available from: doi:10.1016/j.landurbplan. 2015.06.011 [Accessed 16 August 2017].

[50] OECD. OECD Regional Typology. Available from: https://www.oecd.org/cfe/regional-policy/OECD_regional_typology_Nov2012.pdf [Accessed 2 February 2018].

[51] Croatian Bureau of Statistics. Census of Population, Households and Dwellings 2011. Available from: https://www.dzs.hr/default_e.htm [Accessed 16 September 2017].

[52] Schuurman N, Berube M, Crooks VA. Measuring Potential Spatial Access to Primary Health Care Physicians Using a Modified Gravity Model. The Canadian Geographer. 2010;54(1):29-45. Available from: doi:10.1111/ j.1541-0064.2009.00301.x [Accessed 15 November 2017].

[53] Viegas J. Urban Accessibility: perception, measurement and equitable provision. Available from: https:// www.oecd.org/gov/regional-policy/PPT-Viegas.pdf [Accessed 10 October 2018].

[54] Millward H, Spinney J, Scott D. Active - Transport Walking Behaviour: Destinations, Durations, Distances. Journal of Transport Geography. 2013;28: 101-110.

[55] Department for Transport. National Travel Survey. Available from: https://www.gov.uk/government/collections/national-travel-survey-statistics [Accessed 11 October 2018].

[56] Transport Analysis. Travel and commodity flow survey. Available from: http://trafa.se/en/travel-survey/ [Accessed 12 October 2018].

[57] INFAS, DLR. Mobilität in Deutschland 2008. Available from: http://www.mobilitaet-in-deutschland.de/pdf/ infas_MiD2008_Abschlussbericht_I.pdf [Accessed 10 October 2018].

[58] Central Statistics Office. National Travel Survey 2009. Available from: http://www.ucd.ie/t4cms/NTS\%20Report\%202009.pdf [Accessed 12 October 2018]. 